\title{
Physico-chemical analysis of Logone River water at Moundou City in Southern Chad
}

\author{
Ahmat al-Tidjani HISSEIEN ${ }^{1 *}$, Richard KAMGA ${ }^{2}$ and Tchadanaye New MAHAMAT ${ }^{1}$ \\ ${ }^{1}$ Laboratoire de l'Eau et de l'Environnement (LABEEN), Département de Chimie Faculté de Sciences Exactes \\ et Appliquées (FSEA), Université de N'Djamena, Po. Box: 1117 N'Djamena, Tchad. \\ ${ }^{2}$ Laboratoire de Substances Actives et Pollution, Université de Ngaoundéré, \\ Po. Box: 455, Ngaoundéré, Cameroun. \\ *Corresponding author, E-mail: ahmataltidjani@yahoo.fr, Tel: (+235) $66324929 / 99628249$.
}

\begin{abstract}
The physico-chemical parameters and some heavy metal concentrations in the Logone River water at Moundou City, Chad, are studied for two stations from July 2013 to December 2014, one upstream and another downstream of the city. Standard methods are used. A total of twenty-two physico-chemical parameters were determined by spectrophotometers showed clear seasonal variations of; $\mathrm{BOD}_{5}, \mathrm{COD}$, sulphate, phosphate, and nitrate, among the stations. The Moundou City wastewater negatively impacted the concentrations of physicochemical parameters of Logone River water samples when compared with the World Health Organization (WHO) permissible limits. It was observed that the water quality parameters exceed the permissible limits downstream of the river:BOD 5 (198mg/l), COD (897 mg/l), MES (287 mg/l), F(1.87 mg/l), heavy metals Cr (0,934 mg/l), Fe (5,55 mg/l) Cu (0,294 mg/l), Pb (17 mg/l), As (0,894 mg/l), Mb (14,2 mg/l). This study shows that industrial discharge into Logone River seriously contributes to the pollution of the river at the level which poses health and environmental hazards to those using it in downstream for domestic and agricultural purposes. (C) 2015 International Formulae Group. All rights reserved.
\end{abstract}

Keywords: Heavy metals, river water pollution, physico-chemical properties, Logone river, Moundou, Chad.

\section{INTRODUCTION}

Rapid urbanization and industrial development during last decades have negatively affected the environment. Heavy metals contamination of rivers is one of the main problems in many fast growing cities because the maintenance of water quality and sanitation infrastructure do not follow the population and urbanization growth especially in developing countries (Sundaray et al., 2006; Karbassi et al., 2007; Akoto et al., 2008; Ahmad et al., 2010).Trace metals enter the rivers from variety of sources; they can be either natural or anthropogenic (Bem et al., 2003; Wong et al., 2003; Adaikpoh et al., 2005; Akoto et al., 2008). Usually, in unaffected environments, the concentration of most of the metals is very low and is mostly derived from the mineralogy and the weathering (Karbassi et al., 2008). Main anthropogenic sources of heavy metal contamination are mining, disposal of untreated and partially treated effluents contain toxic metals, as well as metal chelates from different industries and indiscriminate use of heavy metal-containing fertilizer and 
pesticides in agricultural fields (Amman et al., 2002; Nouri et al., 2006; Nouri et al., 2008). Metals enter into river water from industrial and urban areas through various ways such as soap, oil brewery, and abattoirs and food factories. A study of spatio-temporal variations in water quality of NullahAiktributary of the river Chenab, Pakistan by Qadir et al. (2008) revealed that the quality of upstream water is better than that of downstream water. The information on water quality and pollution sources is important for implementation of sustainable water-use management strategies (Sarkar et al., 2007; Zhou et al., 2007; Bu et al., 2009).

Logone, is a major river in Chad. Its main pollution sources are industrial, notably chemical, agricultural, and textile. Most of these industries discharge their effluents directly into the Logone River without any treatment, causing pollution of the water. Tchoroun (2012) studied the industrial effluent impacts in the Logone River and came to the conclusion that degree of some metals were above the permissible limits. Pollution from everyday domestic use could also be taken into consideration, as many persons use fresh water and then discharge the wastewater into the river.

The objectives of the present study were (1) To investigate the main polluants and establish their seasonal physico-chemical variation for Logone River water at two different sampling stations (upstream and downstream); and (2) To study their seasonal correlation.

\section{MATERIALS AND METHODS Study area}

Moundou straddles the Logone River, and is the most industrialized city of Chad. Moundou has breweries and factories that produce textiles, soap, vegetable oil (from cotton seed) and tobacco. There is also a factory for building agricultural machines. All of these factories have been operating for many years.

We have the following water use information about the above mentioned factories. The textile industry discharges approximately $14 \mathrm{~m}^{3} / \mathrm{h}$ of wastewater into the Logone River; the brewery discharges about $22 \mathrm{~m}^{3} / \mathrm{h}$; and the vegetable oil factory discharges about $0,17 \mathrm{~m}^{3} / \mathrm{h}$.

This study was conducted during the following period: July 2013, May 2014 and December 2014 at two different selected sampling sites along the Logone River upstream and downstream of the city of Moundou (Figure 1). Metal concentration in river water from upstream to downstream is illustrated in Tables 2, 3 and 4.

\section{Water sampling and preservation}

The water samples for this study were collected from upstream and downstream stations of the river in $250 \mathrm{~mL}$ polyethylene bottles, previously cleaned by detergent and rinsed with sampled water three times, and filled to the brim at depth less than one meter. The exact locations were recorded using the Global Positioning System (GPS). Some parameters were measured in situ $(\mathrm{pH}$, Conductivity, Dissolved Oxygen, temperature). The samples were labeled and stored at $4{ }^{\circ} \mathrm{C}$, then transported to laboratory for analysis. In this study, the water quality parameters: $\mathrm{pH}$, Temperature, DO, BOD, COD, and Nitrates, Nitrites, Phosphate, Sulphate, heavy metals like $\mathrm{Fe}, \mathrm{Cu}, \mathrm{Mn}, \mathrm{Mb}$, $\mathrm{Al}, \mathrm{As}, \mathrm{Zn}, \mathrm{Cd}, \mathrm{Pb}$ and $\mathrm{Ni}$ were determined for the samples.

\section{Physico-chemical analysis}

The samples were collected and analyzed for temperature electrical conductivity, $\mathrm{pH}$, and dissolved oxygen in situ. The analysis for the majority of the trace metals like chromium $(\mathrm{Cr})$, cadmium $(\mathrm{Cd})$, nickel $(\mathrm{Ni})$, zinc $(\mathrm{Zn})$, cupper $(\mathrm{Cu})$, and iron (Fe) was done by Spectrophotometer 7100 water analysis leader UK, and DR/2400 and Cadmium was assayed by the method of molecular absorption spectrophotometer at $422 \mathrm{~nm}$ against reagent blank using a spectrophotometer (SHIMADZU UV-1700 PC). The determination of COD was made by digestion of potassium dichromate in a 


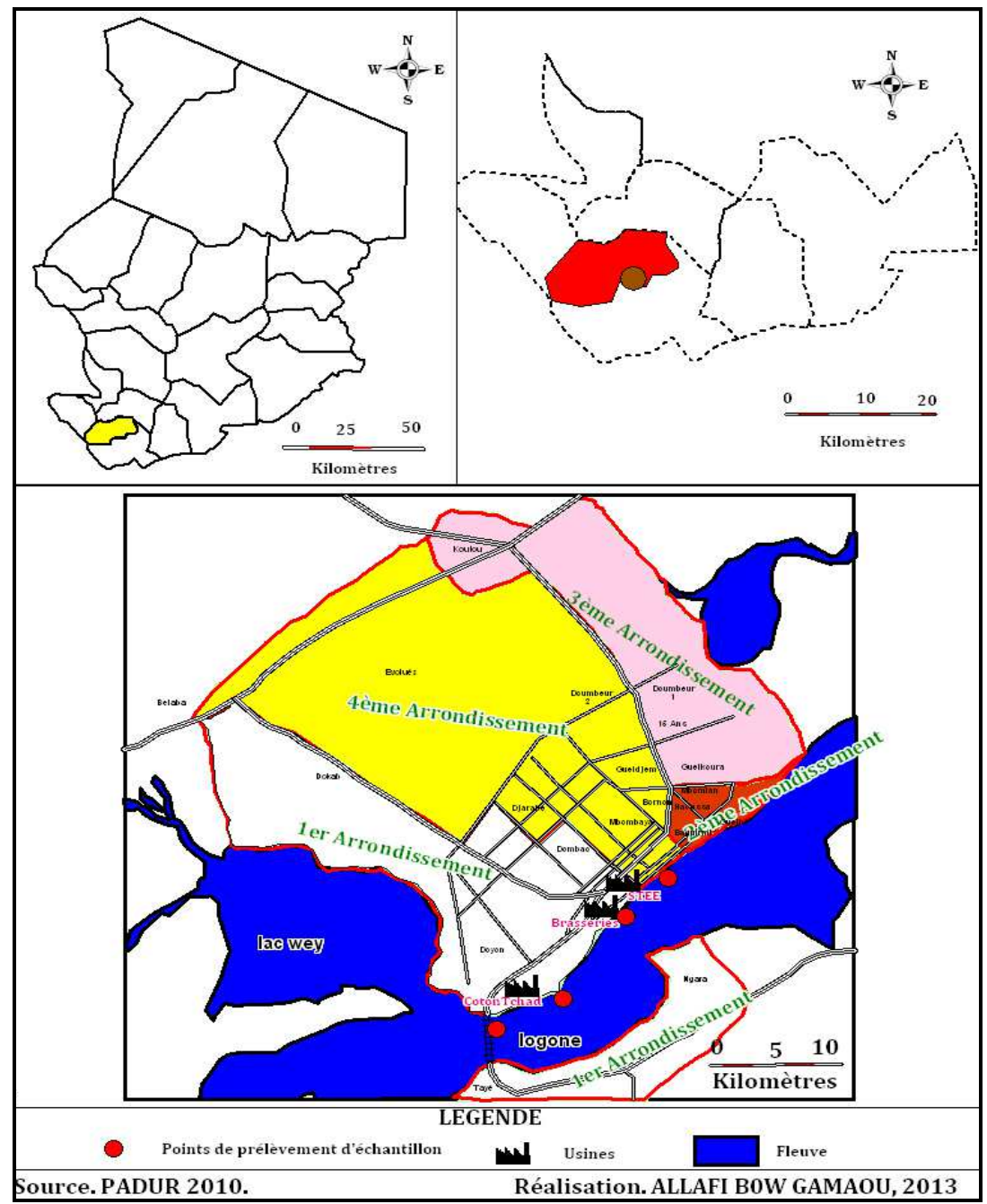

Figure 1: Location map of the study area.

$\mathrm{DR} / 2400 \mathrm{HACH}$ digester at $150{ }^{\circ} \mathrm{C}$ for $2 \mathrm{~h}$ and results were obtained on a DR/2400 spectrophotometer at a wave length of $620 \mathrm{~nm}$ (Hach, 1997). BOD5 was determined by the respirometric BOD $\operatorname{Trak}^{\mathrm{TM}}$ 2000. A $160 \mathrm{~mL}$, aliquot of each sample was introduced into a BOD bottle on the BOD Trak and incubated at $20{ }^{\circ} \mathrm{C}$ for 5 days. Readings were made on the screen of the BOD Trak (Hach, 1997).

\section{Statistical analysis of data}

In our present study, we determined the graphics using Microsoft Office Excel (Microsoft 2010). The data obtained were subjected to analysis for means, standard error and significance between the means at $95 \%$ probability level. These calculations were carried out using STATGRAPHICS 16.

\section{RESULTS}

The experimental data on heavy metal content and physico-chemical properties of water samples collected from Logone River flowing along the city of Moundou industrial area is presented in Tables 2, 3 and 4.

\section{Potential of Hydrogen (pH)}

$\mathrm{pH}$ is a measure of the acidity or alkalinity of water, and is one of the stable measurements. $\mathrm{pH}$ is a simple parameter but is 
extremely important, since most of the chemical reactions in aquatic environment are controlled by any change in its value. Anything either highly acidic or alkaline would kill marine life. In the present study, the average $\mathrm{pH}$ values of Logone River water was 6.27 in upstream and 7.66 downstream.

\section{Temperature}

Temperature is one of the most important ecological features. It controls behavioral characteristics of organisms, solubility of gases and salts in water. During this study, the temperature of the river water varies between $25.5{ }^{\circ} \mathrm{C}$ and $26.0{ }^{\circ} \mathrm{C}$ respectively at the upstream and downstream sampling locations. The mean temperature values of the water samples were not statistically different from each other ( $p>$ 0.05 ) and also fall within the normal temperature range supportive of good surface water quality which is $0{ }^{\circ} \mathrm{C}$ to $30{ }^{\circ} \mathrm{C}$.

\section{Electrical conductivity}

The electrical conductivity (EC) is usually used for indicating the total concentration of charged ionic species in water. The most expedient to evaluate the salinity of water is to measure its electrical conductance. In this study, the electrical conductivity average ranges between 46.6 $\mu \mathrm{S} / \mathrm{cm}$ in upstream in July and $67.6 \mu \mathrm{S} / \mathrm{cm}$ in downstream in May (Figure 2). From the table of analysis of variance $(p>0,05)$, there is not statically significant difference between upstream and downstream for Electrical Conductivity at the level of confidence of $95,0 \%$.

\section{Dissolved Oxygen}

Dissolved oxygen (DO) has significant importance to the respiration activities of the aquatic organisms and effluents, and very low DO may have a negative impact on the sustainability of the rivers in the basin. In the present study, the DO ranges from 6.55 for upstream in rainy season to $7.21 \mathrm{mg} / \mathrm{L}$ for downstream during dry season followed by wet season (Figure 2). The mean DO values of
Logone water for upstream and downstream samples were not significantly different $(\mathrm{p}>$ $0.05)$.

\section{Biological Oxygen Demand}

In the present study, the biological oxygen demand (BOD values in Logone River ranged from $34 \mathrm{mg} / \mathrm{l}$ in upstream in December and $198 \mathrm{mg} / \mathrm{l}$ in downstream in dry season in May. The mean BOD values of Logone water for upstream and downstream samples were not significantly different $(\mathrm{p}>0.05)$.

\section{Chemical Oxygen Demand}

The concentration of chemical oxygen demand (COD) reported in the present investigation was found to vary between 76.34 $\mathrm{mg} / \mathrm{l}$ in upstream of Logone River water in December and $897 \mathrm{mg} / \mathrm{l}$ in downstream in July (rainy season). There was a clear seasonal variation in both BOD and COD; values increased from dry season to rainy season. The mean COD values of Logone water for upstream and downstream samples were not significantly different $(\mathrm{p}>0.05)$.

\section{Suspended Matters MES}

The concentration of suspended matters MES range from $40 \mathrm{mg} / \mathrm{l}$ for upstream in May to $277 \mathrm{mg} / \mathrm{l}$ for downstream in rainy season (July).

\section{Sulphates ions (SO4)}

In this study the concentrations of sulphates value range from $10 \mathrm{mg} / \mathrm{l}$ in upstream in dry season and $56 \mathrm{mg} / \mathrm{l}$ in downstream in rainy season (July).

\section{Phosphate ion (PO4)}

Phosphate ion was not found in Logone River water during the investigation in most seasons. Only in December, a value of 0.001 $\mathrm{mg} / \mathrm{l}$ was recorded for downstream.

\section{Nitrates ion concentration $\left(\mathrm{NO}_{3}{ }^{-}\right)$ \\ Nitrate values in Logone River water ranged from $0.14 \mathrm{mg} / \mathrm{l}$ in upstream in December (winter) and $46.0 \mathrm{mg} / \mathrm{l}$ in July rainy season. Sources of nitrate could be from}


oxidation of other forms of nitrogen compounds like ammonia and nitrite into nitrate. These values were below the permissible limit recommended by WHO (50 $\mathrm{mg} / \mathrm{l})$. There was a clear seasonal variation in both phosphate and nitrate; values increased from dry season to rainy season.

\section{Fluoride}

The fluoride concentration found in the water of Logone River between $1.16 \mathrm{mg} / \mathrm{l}$ in upstream and $1.87 \mathrm{mg} / \mathrm{l}$ in downstream in rainy season July. The average values were below the permissible limit recommended by World Health Organization (1,5 mg/l).

\section{Chromium}

The average concentration of $\mathrm{Cr}$ in water samples was found to vary between $0,04 \mathrm{mg} / \mathrm{L}$ for upstream and $0,934 \mathrm{mg} / \mathrm{L}$ for downstream samples (Figure 4), which was higher than the permissible limit of $0.05 \mathrm{mg} / \mathrm{L}$ set by WHO.

\section{Cadmium}

Cadmium is contributed to surface waters through paints, pigments, glass enamel, deterioration of the galvanized pipes etc. The wear of studded tires has been identified as a source of $\mathrm{Cd}$ deposited on road surfaces. The average $\mathrm{Cd}$ content in water samples was found to vary between $0,0124 \mathrm{mg} / \mathrm{L}$ in upstream and $0,183 \mathrm{mg} / \mathrm{L}$ in downstream of the river (Figure 4).

\section{Nickel}

The average Nickel content in the water samples during the study period was found to vary between $0.06 \mathrm{mg} / \mathrm{L}$ for downstream in rainy season and $0.95 \mathrm{mg} / \mathrm{L}$ for upstream of the river respectively in rainy season (Figure 4).

\section{Zinc}

In the present study, the average concentration of $\mathrm{Zn}$ in upstream and downstream water samples of Logone River was found to be $0,05 \mathrm{mg} / \mathrm{L}$ and $1,06 \mathrm{mg} / \mathrm{L}$ respectively (Figure 4). All concentrations were below the permissible limit of $5 \mathrm{mg} / \mathrm{L}$ recommended by World Health Organization (WHO).

\section{Copper}

Copper is a natural element which is widely distributed in soils, rocks and in rivers and the sea. Copper is widely used in society and yet is potentially quite toxic to life in rivers. The average concentration of Copper content in water samples was found to vary between $0,187 \mathrm{mg} / \mathrm{L}$ for upstream and 0,294 $\mathrm{mg} / \mathrm{L}$ for downstream during all the three seasons (Figure 4).The observed downstream values were above the permissible limit of 0,2 $\mathrm{mg} / \mathrm{L}$ set by WHO.

\section{Lead}

The average concentration of $\mathrm{Pb}$ in water samples was found to be $0.005 \mathrm{mg} / \mathrm{L}$ for upstream and $1,767 \mathrm{mg} / \mathrm{L}$ for downstream (Figure 5), which was much higher than the permissible limit for lead in drinking water $(0.05 \mathrm{mg} / \mathrm{L})$ according to WHO drinking water standards.

\section{Iron}

The maximum $\mathrm{Fe}$ concentrations recorded were $4,55 \mathrm{mg} / \mathrm{l}$ in downstream samples in July (rainy season). This may be attributed to soil-water interaction, especially from heavy rains. The minimum concentrations were found $0,334 \mathrm{mg} / \mathrm{L}$ for upstream samples in December (Figure 5). The mean $\mathrm{Fe}$ values of Logone water samples for upstream and downstream were not significantly different $(\mathrm{p}>0.05)$.

\section{Aluminum \\ No detectable levels of aluminum were found during this study, with the exception of one measurement of $0,014 \mathrm{mg} / \mathrm{l}$ in December. \\ Manganese \\ The element manganese is present in over 100 common salts and mineral complexes that are widely distributed in rocks, in soils, and on the floors of lakes and oceans. Industrial emissions containing manganese oxides are the principal source of manganese}


in the atmosphere. In the present study, no detectable levels of manganese were found, with the exception of one measurement of $0.001 \mathrm{mg} / \mathrm{L}$ in December (Figure 5).

\section{Arsenic}

In our study, the average concentration of arsenic in Logone River water during sampling periods were found $0.05 \mathrm{mg} / \mathrm{L}$ in July (rainy season) in upstream and 0.894 $\mathrm{mg} / \mathrm{L}$ in downstream in December. The last value is highly above the permissible limit recommended by World Health Organization (WHO) which is $0.01 \mathrm{mg} / \mathrm{l}$ (Figure 5).

\section{Molybdenum}

In this study, the average concentration of molybdenum in the river water ranged between $8.034 \mathrm{mg} / \mathrm{l}$ in upstream of the river in December (winter) and $12.4 \mathrm{mg} / \mathrm{l}$ in downstream in May (dry season) as showed in (Figure 5).

Table 1: GPS position of sampling points.

\begin{tabular}{lcc}
\hline Station & Latitude & Longitude \\
\hline Upstream & $05^{\circ} 00^{\prime} 00^{\prime \prime} \mathrm{N}$ & $15^{\circ} 0000^{\prime \prime} \mathrm{E}$ \\
Downstream & $08^{\circ} 33^{\prime} 818^{\prime \prime} \mathrm{N}$ & $16^{\circ} 05^{\prime} 558^{\prime \prime} \mathrm{E}$ \\
\hline
\end{tabular}

Table 2: Physico-chemical parameters of Logone River water at Moundou.

\begin{tabular}{llcc}
\hline R1 & & R2 & WHO \\
\hline $\mathrm{pH}$ & 6,27 & 7,18 & $6,5-85$ \\
Temperature $\quad\left({ }^{\circ} \mathrm{C}\right)$ & 24,5 & 26,7 & $30{ }^{\circ} \mathrm{C}$ \\
Conductivity $(\mu \mathrm{S} / \mathrm{cm})$ & 46,6 & 114 & 1000 \\
Dissolved oxygen $\left(\mathrm{O}_{2} / \mathrm{mg} / \mathrm{l}\right)$ & 6,55 & 7,16 & 5 \\
$\mathrm{MES}(\mathrm{mg} / \mathrm{l})$ & 40 & 277 & 100 \\
$\mathrm{COD}(\mathrm{mg} \mathrm{O} / \mathrm{l})$ & 76,34 & 897 & 90 \\
DBO5 $(\mathrm{mg} \mathrm{O} 2 / 1$ & 34 & 198 & 30 \\
\hline R1: Upstream of the river, R2: Downstream of the river & &
\end{tabular}

R1: Upstream of the river, R2: Downstream of the river

Table 3: Chemical parameters of Logone River in Moundou.

\begin{tabular}{lcccc}
\hline & F & NO3 & SO4 & PO4 \\
\hline Upstream (R1) (mg/l) & 1,16 & 0,14 & 10 & 0,00 \\
Downstream(R2) $(\mathrm{mg} / \mathrm{l})$ & 1,18 & 46,0 & 56 & 0,001 \\
\hline
\end{tabular}

Table 4: Heavy metal concentration in Logone River water at Moundou.

\begin{tabular}{lccccccccc}
\hline & $\mathbf{C r}^{+\mathbf{6}}$ & $\mathbf{C u}$ & $\mathbf{F e}$ & $\mathbf{Z n}$ & $\mathbf{C d}$ & $\mathbf{N i}$ & $\mathbf{P b}$ & $\mathbf{M n}$ & $\mathbf{M b}$ \\
\hline Upstream (R1) (mg/l) & 0,04 & 0,187 & 0,34 & 0,05 & 0,124 & 0,34 & 0,008 & 0,00 & 8,04 \\
Downstream(R2) (mg/l) & 0,934 & 0,294 & 4,55 & 1,06 & 0,012 & 0,27 & 17,67 & 0,001 & 12,4 \\
WHO limits (mg/l) (mg/l) & 0,05 & 0,05 & 0,3 & 5 & 0,01 & 0,1 & 0,01 & 0,05 & 0,2 \\
\hline
\end{tabular}




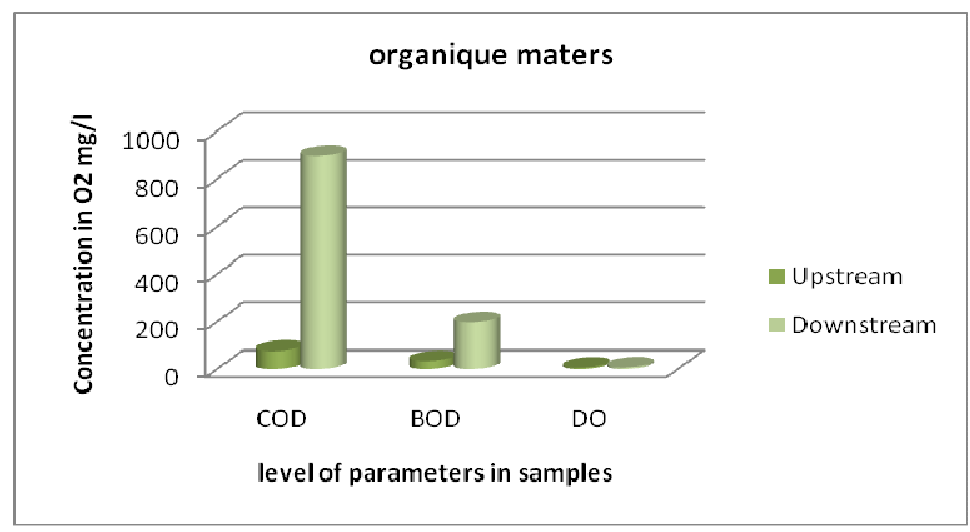

Figure 2: Variations in average physico-chemical parameters in water samples of Logone River.

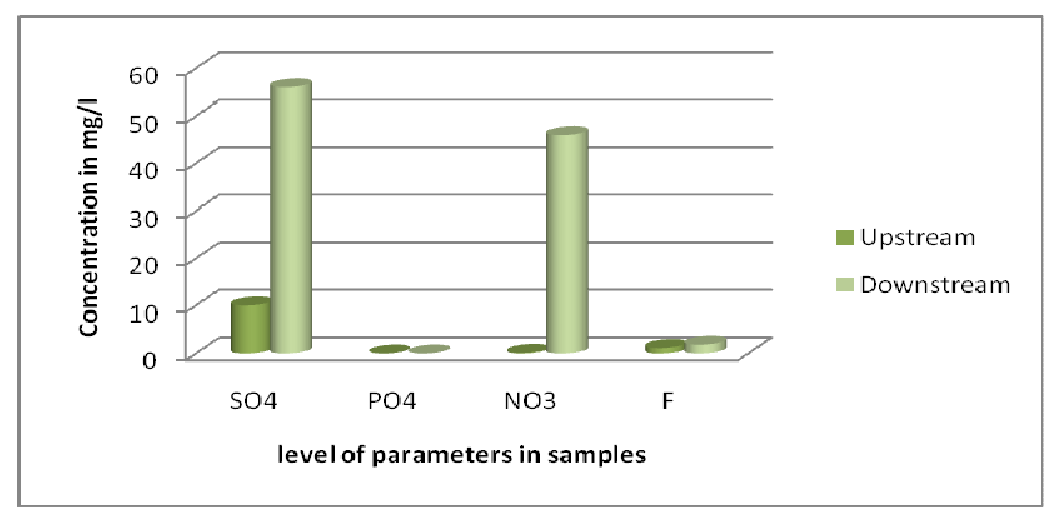

Figure 3: Variations in average of chemical parameter in water samples of Logone River in mg/l.

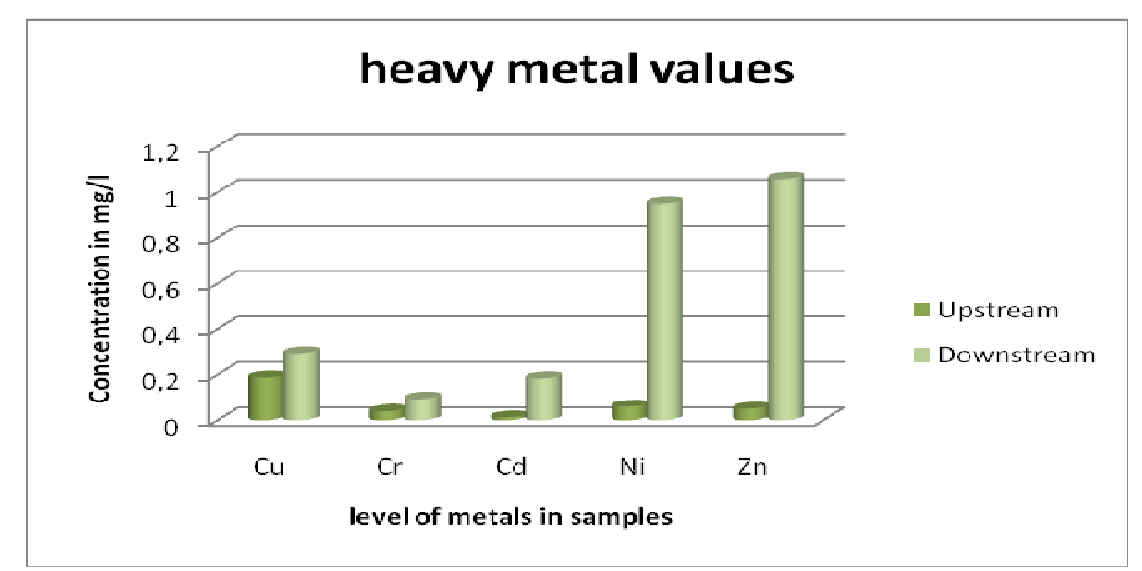

Figure 4: Variation in average concentration of toxic heavy metals in water samples of Logone River in Moundou. 


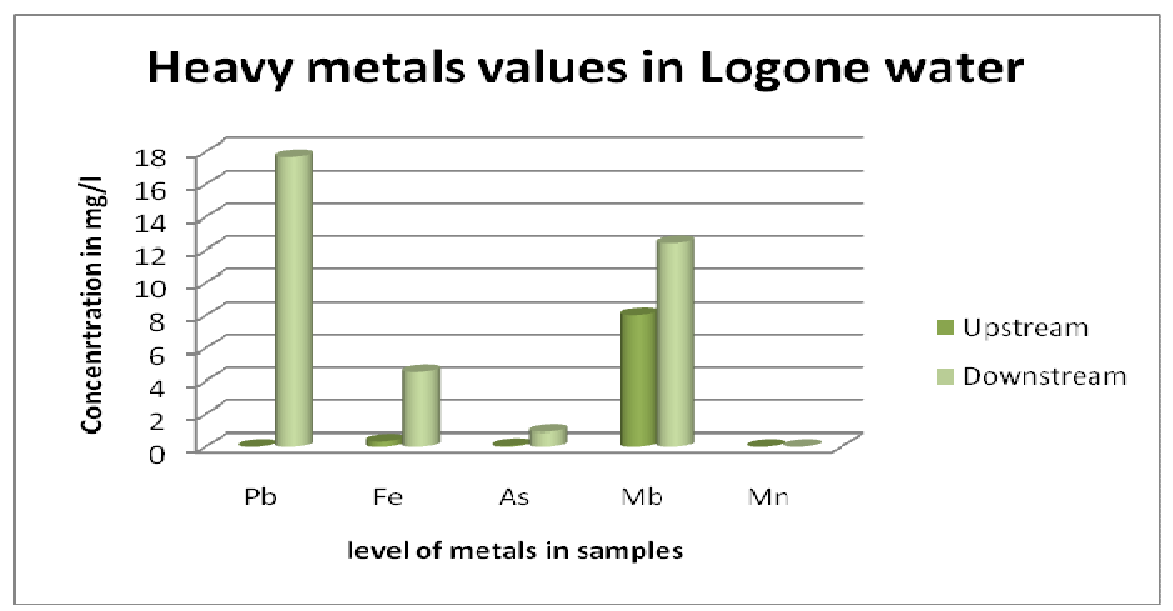

Figure 5: Variation in average concentration of toxic heavy metals in water samples of Logone River in Moundou.

\section{DISCUSSION}

Water quality is neither a static condition of a system, nor can it be defined by the measurement of only one parameter. There is a range of chemical, physical and biological components that affect water quality. These variables provide general indication of water pollution, whereas others enable a direct tracking of pollution sources (Pollution Environment Program.,2000).The $\mathrm{pH}$ of water samples collected from the river was slightly neutral (Table 1), and these values fall within the accepted range of 6.5-8.5 indicative of good water quality by WHO (WHO, 2002; Chapman., 1996). High $\mathrm{pH}$ of the River water may result in the reduction of heavy metal toxicity (Aktar et al., 2010).

The electrical conductivity (EC) and Dissolved Oxygen (DO) were under the permissible limits which is $100 \mu \mathrm{s} / \mathrm{cm}$ and 10 $\mathrm{mg} / \mathrm{l}$ respectively. An adequate supply of dissolved oxygen is essential for the survival of aquatic organism (Dara, 2002).

Chemical Oxygen Demand is a measure of the oxidation of reduced chemicals in water it is commonly used to indirectly measure the amount of organic compounds in water (Kumar et al., 2011).The higher values of BOD and COD values are indicative of the presence of organic and inorganic pollutants, respectively. It may be due to discharges of oil and soap industry (owned by Cotontchad) and the brewery of Moundou. The mean BOD values exceeds the recommended maximum allowable concentration set by the European Union for good quality water for fisheries and other aquatic life, which is $3.0-6.0 \mathrm{mg} / \mathrm{L}$ (Chapman., 1996).It was reported that these parameters i.e., BOD and COD are responsible for odor and taste (Jones-Lee A 1993). The COD usually includes all, or most of the BOD as well as some other chemical demands. The significantly high mean COD $(897 \mathrm{mg} / \mathrm{l})$ values also exceeded the acceptable concentrations for unpolluted surface water quality, which is $20 \mathrm{mg} / \mathrm{L}$ or less.

The high suspended matters MES value $(287 \mathrm{mg} / \mathrm{l})$ occurs in rainy season, because of matter carried by runoff water. Dissolved $\mathrm{SO}_{4}{ }^{-}$ ${ }^{2}$ can be derived from the dissolution of $\mathrm{SO}_{4}$ minerals; oxidation of pyrite and other forms of reduced $\mathrm{S}$; oxidation of organic sulfides in natural soil processes; and anthropogenic inputs, i.e. fertilizers (Grasby et al., 1997).

Some heavy metals concentrations in Logone water found during the present study were higher than the limit recommended by World Health Organization (WHO). The highest downstream concentration of chromium ion was $0.934 \mathrm{mg} / \mathrm{L}$, which is 
higher than the permissible limit of $0.05 \mathrm{mg} / \mathrm{L}$ set by WHO (APHA, 1995). The sources of emission of $\mathrm{Cr}$ in the surface waters are from municipal wastes, laundry chemicals, paints, leather, road runoff due to tire wear, corrosion of bushings, brake wires and radiators, etc. The high level of $\mathrm{Fe}(4.55 \mathrm{mg} / \mathrm{l})$ in downstream during rainy season indicate that the composition of the soil region contain high level of iron. The presence of high concentration of $\mathrm{Fe}$ may increase the hazard of pathogenic organisms; since most of these organisms need $\mathrm{Fe}$ for their growth (Tiwana et al., 2005). The highest observed downstream concentration of $\mathrm{Cu}(0,294 \mathrm{mg} / \mathrm{l})$ is higher than the recommended limit set by WHO $(0,02 \mathrm{mg} / \mathrm{l})$. This may be attributed to domestic sewage and runoff from the extensive farmed area (Wu et al., 2008). Also, the highest downstream concentration of $\mathrm{Cd}$ in Logone water found $(1,767 \mathrm{mg} / \mathrm{l})$, which occurred in winter season, is higher than the limiting value of $0,01 \mathrm{mg} / 1$ recommended by WHO. The major source of $\mathrm{Cd}$ is coal combustion, metal industry and waste incineration (Brian and Bishop, 2009). The maximum downstream value of $\mathrm{Ni}$ was $0,95 \mathrm{mg} / \mathrm{L}$, which occurred in summer season. $\mathrm{Ni}$ can cause allergic reactionsm apart from being carcinogenic (McKenzic and Smythe, 1998).The highest $\mathrm{Mn}$ value was $0,001 \mathrm{mg} / \mathrm{L}$, which occurred during winter season. Many key studies documenting the neurotoxic effects of Mn in children (Wasserman et al., 2006 ; Bouchard et al., 2007, 2011; Henn et al., 2011) and adults (Huang 2007; Perl and Olanow 2007; Lucchini et al., 2009) were published within the past 5 years. The highest downstream value of Zinc $(1,06 \mathrm{mg} / \mathrm{l})$ was obtained in rainy season. Zinc is one of the essential elements required for proper functioning of the body system (Raja and Venkatesan, 2010).

\section{Conclusion}

The present study data indicate that there is a significant pollution of Logone River water from industrial activity in the city of Moundou. The water quality of Logone
River is deteriorated due to anthropogenic activities such as industrial use of water and discharge of untreated wastewater into the river. From this investigation, it can also be concluded that metal concentrations in dry season tend to be higher than in rainy season since the flow velocity of Logone River is decreased. As a result, the pollution load in dry season is more important when compared to other seasons.

The validity of the results obtained from Logone River water is supported by correlations found between the variables. The obtained BOD, COD, and some heavy metal values exceed the permissible limit of WHO, which shows that the contamination of water produced decline in DO of the water, which affects the sustainable life of plant and animals in the river. We recommend that strict measures should be taken, such as industrial wastewater and sewage water treatment, and to monitor their discharge into the environment to prevent the pollution of Logone River water.

\section{ACKNOWLEDGEMENTS}

The authors thank French cooperation and Government of Chad through the Ministry of high education for their kind cooperation and the financial support of this study. We also thank Mr. TEDEBAYE Rougoumfor giving technical assistance.

\section{REFERENCES}

Adaikpoh EO, Nwajei GE, Ogala JE. 2005. Heavymetals concentrations in coal and sediments from river Ekulu in Enugu, Coal City of Nigeria. J. Appl. Sci. Environ. Manag., 9(3): 5-8.

Ahmad MK, Islam S, Rahman S, Haque MR, Islam MM. 2010. Heavy metals in water, sediment and some fishes of Buriganga River, Bangladesh. Int. J. Environ. Res., 4(2): 321-332.

Akoto O, Bruce TN, Darko G. 2008. Heavy metals pollution profiles in streams serving the Owabi reservoir. African $J$. Environ. Sci. Tech., 2(11), 354-359. 
Aktar MW, Paramasivam M, Ganguly M, Purkait S, Sengupta D. 2010. Assessment and occurrence of various heavy metals in surface water of Ganga River around Kolkata: a study for toxicity and ecological impact. Environ. Monitor. Assess, 160(1-4): 207-213.

American Public Health Association APHA.1995. Standard Methods for Estimation of Water and Wastewater (19th edn). American Water Works Association, Water environment Federation: Washington.

Bem H, Gallorini M, Rizzio E, Krzemin SM. 2003. Comparative studies on the concentrations of some elements in the urban airparticulate matter in Lodz City of Poland and in Milan, Italy. Environ. Int., 29(4): 423- 428.

Bouchard forest F,Vandelac L, Bellinger D, Mergler D. 2007. Hair manganese and hyperactive behaviors: pilot study of school-age children exposed through tap water. Environ Health Perspect., 115: 122-127.

Brian SC, Bishop M. 2009. Seasonal and spatial variation of metal loads from natural flows in the upper Tenmile Creek watershed, Montana. Mine Watern Environ., 28(3): 166-181.

Bu H, Tan X, Li S, Zhang Q. 2009. Water quality assessment of the Jinshui River (China) using multivariate statistical techniques, Environmental Earth Sciences, 60(8): 1631-1639.

Dara SS. 2002. A text Book of environmental Chemistry and pollution Control. S. Chand and Company Limited: New Delhi, 216.

Hatje V, Bidone ED, Maddock JL. 1998. Estimationof the natural and anthropogenic components of heavy metal fluxes in fresh water Sinos river, Rio Grande do Sulstate, South Brazil. Environ. Tech., 19(5): 483-487.

Huang CC. 2007. Parkinsonism induced by chronic manganese intoxication-an experience in Taiwan. Chang Gung Med., 30(5): 385-395.
Jones-Lee A. 1993. Landfills and Groundwater Pollution Issue Dry Tomb vs. F/L Wet Cell. Proceedings of Sardinia 93: Fourth International Landfill Symposium; Cagliari, Italy. 11-15 October, pp. 1-10.

Karbassi AR, Nouri J, Ayaz G O. 2007. Flocculation of trace metals during mixing ofTalar river water with Caspian Seawater. Int. J. Environ. Res., 1(1): 6673.

Lucchini RG, Martin CJ, Doney BC. 2009. Frommanganism to manganese-induced parkinsonism: a conceptual model based on the evolution of exposure. Neuromolecular Med., 11(4): 311-321.

Mahananda HB. Mahananda M R, Mohanty BP. 2005. Studies on the physicochemical and biological parameters of a fresh water pond ecosystem as an indicator of water pollution. Ecology Environment and Conservation, 11(3-4): 537 - 541.

McKenzic HA, Smythe LE. 1998. Quantitative Trace Analysis of Biological. Elsevier: Amsterdam.

Tiwana NS, Jerath N, Singh G, Ravleen M, 2005. Heavy metal pollution in Punjab rivers'. In Newsletter Environ-mental Information System (ENVIS), (vol 3). Punjab State Council for Science and Technology, Punjab State: India; 3-7.

Nouri J, Mahvi AH. Babaei A, Ahmadpour E. 2006. regional pattern distribution of groundwater fluoride inthe shush aquifer of khuzestan county iran fluoride. Fluoride, 39(4): 321-325.

Nouri J, Mahvi AH, Jahed GR, Babaei AA. 2008. Regional distribution pattern of groundwater heavy metalsresulting from agricultural activities. Environ. Geo., 55(6): 1337-1343.

Pollutions Environment Programme Global Environment Monitoring System. 2000. Water Programme.Water Quality for Ecosystem and Human Health. National Water Research Institute: Burlington, ON, Canada. 
Raja G, Venkatesan P. 2010. Assessment of Groundwater pollution and its impact in and around Punnam area of Karur district', Tamilnadu, India. E. Journal of Chemistry, 7(2): 473-478.

Sarkar SK, Saha M, Takada H, Bhattacharya A, Mishra P, Bhattacharya B. 2007. Water quality management in the lower stretch of the River Ganges, east coast of India: an approach through environmental education, Journal of Cleaner Production, 15(16): 1559-1567.

Sundaray SK, Panda UC, Nayak BB, Bhatta D. 2006. Multivariate statistical techniques for the evaluation of spatial and temporal variation in water quality of Mahanadi river-estuarine system (India).A case study. Environ. Geochem. Health, 28(4): 317-330.

Tchoroun MD. 2012. Evaluation de la contamination en métaux lourds des sediments, des poisons et des eaux du fleuve Logone au niveau de la ville de Moundou. Mémoire de Master II.
Wasserman Liu X, Parvez F, Ahsan H, Levy D, Factor-Litvak P. 2006. Water manganese exposure and children's intellectual function in Araihazar, Bangladesh. Environ Health Perspect., 114: 124-129.

WHO. 2002. Drinking Water Guidelines: Bacteriological Parameters (vol. 13). WHO: Geneva, Switzerland.

Zhou F, Huang GH, Guo HC, Zhang W, Hao ZJ. 2007. Spatio-temporal patterns and source apportionment of coastal water pollution in eastern Hong Kong. Water Research, 41(15): 3429-3439.

Wong CSC, Li, XD, Zhang G, Qi SH, Peng XZ. 2003. Atmospheric deposition of heavy metals in the Pearl River Delta, China.Atmos. Environ., 37(6): 767-776.

Wu YF, Liu CQ, Tu CL. 2008. Atmospheric deposition of metals in TSP of guiyang. PR China. Bull. Environ. Contam. Toxicol., 80(5): 465-468. 